Int. J. Electrochem. Sci., 12 (2017) 8447 - 8456

International Journal of

ELECTROCHEMICAL

SCIENCE

www.electrochemsci.org

\title{
Electrochemical Immunoassay Determination of a Cancer Biomarker (CA19-9) by Horseradish Peroxidase
}

\author{
Songyan Zhang ${ }^{1}$, Chengming Sun ${ }^{1}$ and Wenping Zhou ${ }^{2, *}$ \\ ${ }^{1}$ Department of Hepatopancreatobiliary Surgery, Harbin Medical University Cancer Hospital, Harbin \\ 150040, China \\ ${ }^{2}$ Department of Hepatobiliary Surgery, General Hospital of Shenyang Military, 83 Wenhua Road, \\ Shenhe District, Shenyang 110016, Liaoning Province, China. \\ *E-mail: wenpingzhou_sunny@163.com
}

doi: $10.20964 / 2017.09 .31$

Received: 14 May 2017 / Accepted: 2 July 2017 / Published: 13 August 2017

This work developed an electrochemical immunosensor to quantitatively detect CA19-9 in human serum, a pancreatic cancer biomarker, where the electrode materials were thionine (TH) and graphene sheets (GS), and horseradish peroxidase (HRP) and ferroferric oxide $\left(\mathrm{Fe}_{3} \mathrm{O}_{4}\right)$ nanoparticles-loaded mesoporous silica nanoparticles (MSNs) served as labels to amplify signals. The electron transfer and immobilization of primary antibody of CA19-9 $\left(A b_{1}\right)$ were enhanced by the as a substrate, the GS and TH hybrid (GS/TH). MSNs were used as a carrier for immobilization of secondary antibody of CA19$9\left(\mathrm{Ab}_{2}\right), \mathrm{Fe}_{3} \mathrm{O}_{4}$, and HRP. The sensitivity of the immunosensor could be enhanced by the synergistic effect between HRP and $\mathrm{Fe}_{3} \mathrm{O}_{4}$. The proposed technique is potential to be applied to clinical analysis or be used to detect other tumor markers.

Keywords: Pancreatic cancer; Biomarker; Graphene; CA19-9; Horseradish peroxidase

\section{$\underline{\text { FULL TEXT }}$}

(C) 2017 The Authors. Published by ESG (www.electrochemsci.org). This article is an open access article distributed under the terms and conditions of the Creative Commons Attribution license (http://creativecommons.org/licenses/by/4.0/). 